\title{
Soil Agricultural Potential in Four Common Andean Land Use Types in the Highlands of Southern Ecuador as Revealed by a Corn Bioassay
}

\author{
Gustavo Chacón ${ }^{1}$, Daniel Gagnon ${ }^{2}$, David Paré ${ }^{3}$ \\ ${ }^{1}$ Department of Biology, Ecology and Management, Universidad del Azuay, \\ Cuenca, Ecuador \\ ${ }^{2}$ Department of Biology, Faculty of Science, University of Regina, Regina, \\ Canada, \\ ${ }^{3}$ Natural Resources Canada, Canadian Forest Service, Laurentian Forestry Centre, \\ Sainte-Foy, Canada \\ Email: "gchacon@uazuay.edu.ec, daniel.gagnon@uregina.ca, david.pare@rncan-nrcan.gc.ca
}

Received 1 September 2015; accepted 9 October 2015; published 12 October 2015

Copyright (C) 2015 by authors and Scientific Research Publishing Inc.

This work is licensed under the Creative Commons Attribution International License (CC BY). http://creativecommons.org/licenses/by/4.0/

(c) (i) Open Access

\section{Abstract}

In the Andes, little is known about the relationships among current land uses and their effect on soil fertility. Corn (Zea mays L.) was used to evaluate soil quality for plant growth on soils of four land uses, along an expected gradient of fertility: native forests $(\mathrm{Nf})>$ pastures $(\mathrm{Pa})>$ Eucalyptus globulus Labill. plantations (Eg) > Pinus patula Schlecht. plantations (Pp). Corn was grown in soils taken from four different areas, for the four land uses in each. In a common garden, a randomized block design was used with four treatments: controls $(\mathrm{C})$, ammonium nitrate $(\mathrm{N})$, triple superphosphate $(\mathrm{P})$, and combined $\mathrm{N}$ and $\mathrm{P}$ fertilizers $(\mathrm{N}+\mathrm{P})$. On soils from $\mathrm{Nf}$, $\mathrm{Pa}$ and Eg, fertilization response was $\mathrm{N}+\mathrm{P}>\mathrm{P}>\mathrm{N}>\mathrm{C}$; corn biomass $\left(\mathrm{g} /\right.$ pot $\left.^{-1}\right)$ averaged 4.5 in $\mathrm{N}+\mathrm{P}, 3.3$ in $\mathrm{P}, 1.8$ in $\mathrm{N}, 1.7$ in $C$; $P$ content (mg/pot $\left.{ }^{-1}\right)$ averaged 12 in $N+P, 11.9$ in $P, 2.3$ in $N, 2$ in $C . N+P$ enhanced growth the most. Mortality was high on Pp soils, growth weak, and fertilization response was $\mathrm{P}>\mathrm{N}+\mathrm{P}>\mathrm{C}$ $\geq \mathrm{N}$; corn biomass $\left(\mathrm{g} / \mathrm{pot}^{-1}\right)$ was 0.9 in $\mathrm{P}, 0.5$ in $\mathrm{N}+\mathrm{P}, 0.8$ in $\mathrm{C}, 0.4$ in $\mathrm{N}$; $\mathrm{P}$ content $\left(\mathrm{mg} / \mathrm{pot}^{-1}\right)$ was 4.4 in $P, 2.3$ in $N+P, 1.8$ in $C, 1$ in $N$. All soils had $P, K$, Ca and Mg deficiencies. Al toxicity possibly occurred only in Pp soils. All control soils had low fertility. Responses to $\mathrm{N}$ and $\mathrm{P}$ were high except for Pp. Pastures and plantations were once natural forests converted to agriculture, then to pastures as soil fertility declined. Plantations were likely established on poorest pastures; only pine grew on poorest soils. This land use endpoint has the lowest agricultural potential; other land uses

\footnotetext{
${ }^{*}$ Corresponding author.
} 
have limitations in $P, N$, and potentially $K$.

Keywords

Andosol, Nutrient Deficiencies, Land Use Impacts, Montane Forests, Paute Watershed

\section{Introduction}

Throughout the last five decades, the agricultural sector in the high Andes of Ecuador has experienced political and social changes that have promoted a rapid expansion of agricultural and forestry land use. On one hand, these changes have caused a reorientation of cultivation practices towards large-scale agri-businesses motivated by increased food exportation [1] [2]. On the other hand, small to medium-sized farmers (from $<1$ ha to $5 \mathrm{ha}$ ) are putting demands on land with soils that are already nutrient-limited in most of the Andes, due to intensive cultivation and pasturing, afforestation and soil erosion processes [3]-[5]. The increase in land use without regard to soil nutrient replenishment by both large-scale farming enterprises and small to medium sized farmers has, in turn, led to the rapid decline of soil fertility and possibly to an irreversible transformation of native forests into farmlands, pastures or tree plantations [6]-[10].

The loss of soil fertility, increased rates of rainfall runoff and accelerated water erosion in the high Andes are current and serious concerns [11]. Evidence from the northern and central Ecuadorian Andes suggests that present-day soil conditions generally show nitrogen and phosphorus deficiencies that may limit agricultural use, with phosphorus as the principal limiting factor [3] [12]. However, P deficiencies are also linked to the properties of volcanic ash soils in the highlands of Ecuador [7] [13] [14]. Volcanic ash soils have important P pools in organic forms [15]. However, inorganic forms are readily fixed and adsorbed [16] due to the presence of amorphous sesquioxides of $\mathrm{Fe}$ and $\mathrm{Al}$, and organometallic complexes in these soils [17] [18].

The exotic trees Eucalyptus globulus Labill. [19] and Pinus patula Schlecht. are widely preferred in local forestry plantations because of their fast growth, timber production and their use in pilot carbon sequestration projects [20] [21]. Our extensive analysis of soil properties in various land use situations [10] suggests that plantations of $P$. patula may be the last stage in a sequence of soil degrading land uses, beginning with cutting of the original native forest stands, through agricultural crop production and eventually pasturing, which have resulted in sequential soil degradation and impoverishment. Pastures are presently the dominant land use type in the landscape among scattered remnants of second growth native forests. Pasture soils may be so poor as to be only suitable for planting with tree species tolerant of low soil nutrients, such as $P$. patula [10]. The situation of E. globulus plantations is more complex because they have generally been planted at lower elevations where environmental conditions are less extreme and better soils are found [19]. We have hypothesized that previous land use has lowered soil productivity independent of the type of vegetation cover; however, it is also very likely that there has been a general degradation of soil properties caused by $P$. patula and its litter, especially through the effect of lower soil $\mathrm{pH}$ and cation concentrations [10].

Identifying which soil nutrients are most affected by the various types of land use and the extent to which soils have lost their agricultural potential (plant biomass production capacity) has important implications for future land use planning. Of particular concern is whether subsequent rotations of $P$. patula can be established, or if a return to pasture or annual crops is possible.

Therefore, the objective of this study was to measure the growth of a common Andean agricultural crop, corn (Zea mays L.), in soils from several common Andean land use types, varying from native forest stands, pastures, and to exotic tree plantations (E. globulus and P. patula). Furthermore, we measured the effect of phosphorus and nitrogen fertilization on corn grown in these soils to see if growth was improved. Specifically, the following hypotheses were formulated: 1 ) generally, $\mathrm{P}$ will be more depleted than $\mathrm{N}$ in these volcanic ash Andean soils; 2) P depletion will increase with: a) increasing intensity of soil use or history of use (shown by a stronger effect of fertilization on corn growth), or b) the presence of non-native vegetation (exotic plantations > pastures > native forests); and 3) soils from pine plantations will produce slower growth of corn and less reaction to $\mathrm{N}$ and $\mathrm{P}$ fertilization than soils from eucalyptus plantations because of their lower soil $\mathrm{pH}$ and cation concentrations. 


\section{Materials and Methods}

\subsection{Bioassay of Soils}

Soils from four different land use types were sampled in four geographically different regions where the same four land use types were present, within and out of the Paute watershed in the southern Ecuadorian Andes (Figure 1). The four land use types were: 1) second growth native forest (Nf), 2) pasture (Pa), 3) Pinus patula Schlecht. plantation (Pp), and 4) Eucalyptus globulus Labill. plantation (Eg). Land use types from all regions were located at an average elevation of $3135 \mathrm{~m}$, and ranged between $2950 \mathrm{~m}$ to $3450 \mathrm{~m}$. Regions 1 and 2 (Figure 1) are located in the central mountain chain and receive the influence of rain-laden air from the Amazon basin. In these regions, large differences in elevation cause higher orographic precipitation than in the rest of the watershed. The total annual rainfall averages between $1050 \mathrm{~mm}$ and $1700 \mathrm{~mm}$ [22]. Regions 3 and 4 are located in the south of the Paute watershed. Here, total annual rainfall ranges between $660 \mathrm{~mm}$ and $1100 \mathrm{~mm}$ [22] (Figure 1). According to Buytaert et al. [18] the soils in the northern part of the Paute watershed are classified as Histic Andosols (Regions 1 and 2), and as Dystric Histosols in the southern part of the watershed (Regions 3 and 4) because of lower soil $\mathrm{Al}$ and Fe content (Figure 1). Buytaert et al. [18] described these soils as very darkly colored humic soils, due to the effect of a cold wet climate, and the formation of organometallic complexes driven by a stronger effect of Holocenic volcanic ash (from the Quaternary volcanic activity in the northern Andes of Ecuador). The influence of volcanic ash diminishes towards the south of the Paute watershed, where climate alone is probably responsible for the accumulation of organic soil matter. Organic matter accumulation also determines the high porosity and water retention capacity of these soils. These highland soils have developed on Cretaceous and early Tertiary sediments on the western mountain chain. On the eastern mountain chain, soils have developed on volcanic deposits and on Palaeozoic metamorphic rocks [9] [18] [23].

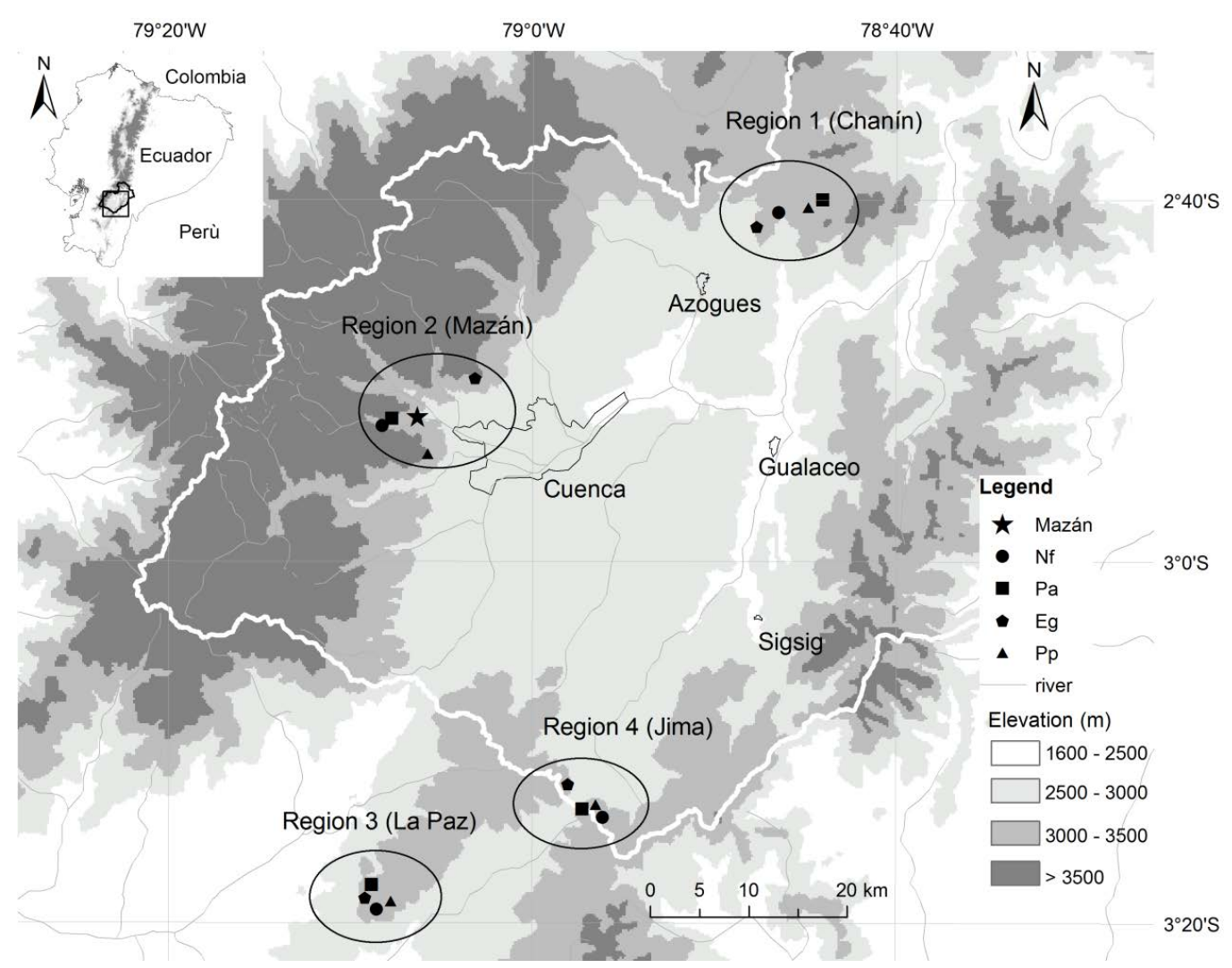

Figure 1. Map of the Paute watershed in southern Ecuador. Indicated are the locations of the four sampling regions and within each region the locations where four land use type soils were collected for analysis. $\mathrm{Nf}=$ native forest, $\mathrm{Pa}=$ pasture, Eucalyptus globulus plantation, $\mathrm{Pp}=$ Pinus patula plantation. Region 2 (Mazán) is where the bioassay experiment was conducted. The outer white line indicates the boundary of the watershed. Main cities are shown. 
All sites that were sampled had similar slopes and quality of soil drainage. For the native forests and E. globulus plantations, no age assessment was possible. The native forests were currently being used for selective fuel wood extraction, and the E. globulus plantations were growing in their second or third resprouting stages. The $P$. patula plantations ranged in age from 15 to 17 years. All were first rotations, and no fertilization had occurred. All pastures from which soil samples were taken were actively used by grazing cattle. The choice of the forested stands was made according to: 1) closed canopy and the presence of shrubs and trees taller than four meters with trunk diameters at breast height $(\mathrm{DBH}) \geq 5 \mathrm{~cm}$ for the native forests, and 2) stands with trees of homogenous DBH $(\geq 20 \mathrm{~cm})$ for the plantations.

\subsection{Soil Sampling, Sample Preparation and Experimental Design}

In each of the land use types, for each of the four regions, a $20 \mathrm{~m} \times 20 \mathrm{~m}$ plot was established. Approximately $0.05 \mathrm{~m}^{3}$ of soil was collected from the first $20 \mathrm{~cm}$ of surface soil in five sub-sampling points within each of the plots (four corners and the centre of the $20 \mathrm{~m} \times 20 \mathrm{~m}$ grid). Soils from each of the sub-sampling points were pooled into one sample for each plot and transported to a common garden in the Río Mazán preserve (Region 2, Figure 1). Soils were sieved through a $1 \mathrm{~cm}$ mesh, removing roots, macro-fauna, and large rocks. Plastic pots (5 $\mathrm{L}$ total volume) were pierced on the bottom, and silica was added to approximately $1 \mathrm{~L}$ volume to facilitate drainage. The remainder of each pot was filled with $4 \mathrm{~L}$ of soil. A portion of soil per pot was taken to the laboratory for chemical analyses.

A randomized block design was established so that each of the four regions corresponded to each of four blocks (Figure 2). Within each of the blocks, each of the four land use types of soils were divided in four sub-units (four pots) and subjected to four separate treatments (control, nitrogen, phosphorus, and $\mathrm{N}+\mathrm{P}$ fertilizers). This design produced 16 randomly distributed combinations of controls and three fertilizer treatments using four land use types of soil per block ( 4 regions (replicates) $\times 4$ land use types $\times 4$ treatments $=64$ experimental units) (Figure 2). The four blocks consist of soils from the four regions and serve as replicates. Subsequently, six corn (Zea mays L.) seeds obtained from a local market were planted in each of the pots. The pots were monitored daily and the first two seeds that germinated were left to grow; the other seeds/seedlings were removed; this gives two corn plants per pot, in each of the 64 pots that were analyzed in this experiment. Fertilizer treatments were made once a week during 98 days (March and June 1999). N-fertilized soils received weekly additions of $175 \mathrm{mg}$ of $\mathrm{N}$ (ammonium nitrate- $\mathrm{NH}_{4} \mathrm{NO}_{3}$ fertilizer). P-fertilized soils received weekly additions of 110 mg of $\mathrm{P}$ (triple superphosphate- $\mathrm{Ca}\left(\mathrm{H}_{2} \mathrm{PO}_{4}\right)_{2} \cdot \mathrm{H}_{2} \mathrm{O}$ fertilizer). Triple superphosphate has $13 \%$ of $\mathrm{Ca}$, which also gives a total of $65 \mathrm{mg}$ of $\mathrm{Ca}$ added weekly to P-fertilized soils. NP-fertilized soils received weekly $87.5 \mathrm{mg}-\mathrm{N}$, $55 \mathrm{mg}-\mathrm{P}$ and $32.5 \mathrm{mg}$-Ca (half of ammonium nitrate and triple superphosphate combined fertilizers).

\subsection{Laboratory Analyses}

At the end of three months, each of the two plants of Zea mays L. per pot was carefully separated from the soil and washed. Each plant consisted of leaves, stem and roots as flowers or fruits were absent at this immature plant state. Each plant was taken to the laboratory in individual sealed plastic bags.

Plant tissues were oven dried at $50^{\circ} \mathrm{C}$ for 72 hours. Each individual plant was weighed separately to measure biomass. For chemical analyses, the two plants of each pot were combined into one sample. Tissues were

\begin{tabular}{|c|c|c|c|c|c|c|c|c|c|c|c|c|c|c|c|}
\hline \multicolumn{4}{|c|}{ Block 1 (region 1: Chanín) } & \multicolumn{4}{|c|}{ Block 2 (region 2: Mazán) } & \multicolumn{4}{|c|}{ Block 3 (region 3: La Paz) } & \multicolumn{4}{|c|}{ Block 4 (region 4: Jima) } \\
\hline $\begin{array}{l}\mathrm{Pp}- \\
\mathrm{N}+\mathrm{P} \\
\end{array}$ & Eg-P & $\begin{array}{l}\text { Eg- } \\
\mathrm{N}+\mathrm{P} \\
\end{array}$ & $\mathrm{Nf}-\mathrm{N}$ & Eg-N & $\begin{array}{l}\text { Eg- } \\
\mathrm{N}+\mathrm{P}\end{array}$ & $\begin{array}{l}\text { Pp- } \\
\text { P }\end{array}$ & Eg-C & $\begin{array}{l}\text { Nf- } \\
\mathrm{P} \\
\end{array}$ & Eg-P & $\begin{array}{l}\text { Pp- } \\
\mathrm{N}\end{array}$ & $\mathrm{Pp}-\mathrm{C}$ & $\begin{array}{l}\text { Pp- } \\
\text { C }\end{array}$ & $\begin{array}{l}\mathrm{Pp}- \\
\mathrm{N}+\mathrm{P} \\
\end{array}$ & Eg-N & $\begin{array}{l}\text { Nf- } \\
\mathrm{N} \\
\end{array}$ \\
\hline Pp-P & Pp-C & Pa-P & Nf-C & $\begin{array}{l}\mathrm{Pa}- \\
\mathrm{N}+\mathrm{P}\end{array}$ & $\mathrm{Pa}-\mathrm{P}$ & $\begin{array}{l}\text { Eg- } \\
\mathrm{P}\end{array}$ & $\begin{array}{l}\text { P p- } \\
\text { N }\end{array}$ & $\begin{array}{l}\text { Eg- } \\
\mathrm{C}\end{array}$ & $\mathrm{Pa}-\mathrm{N}$ & $\begin{array}{l}\text { Nf- } \\
\text { N }\end{array}$ & $\begin{array}{l}\text { Nf- } \\
\mathrm{N}+\mathrm{P}\end{array}$ & $\begin{array}{l}\text { Pp- } \\
\text { P }\end{array}$ & $\mathrm{Pa}-\mathrm{P}$ & $\mathrm{Pa}-\mathrm{N}$ & $\begin{array}{l}\text { Eg- } \\
\text { C }\end{array}$ \\
\hline $\mathrm{Pa}-\mathrm{C}$ & $\begin{array}{l}\text { Nf- } \\
\mathrm{N}+\mathrm{P}\end{array}$ & Eg-C & $\mathrm{Pa}-\mathrm{N}$ & Nf-C & $\begin{array}{l}\text { Nf- } \\
\text { N+P }\end{array}$ & $\begin{array}{l}\text { Pp- } \\
\text { C- }\end{array}$ & Nf-P & $\begin{array}{l}\text { Pa- } \\
\text { P }\end{array}$ & $\begin{array}{l}\text { Pp- } \\
\text { N+P }\end{array}$ & $\begin{array}{l}\text { Pp- } \\
\text { P }\end{array}$ & $\begin{array}{l}\mathrm{Pa}- \\
\mathrm{N}+\mathrm{P}\end{array}$ & $\begin{array}{l}\text { Pp- } \\
\text { N }\end{array}$ & $\begin{array}{l}\text { Nf- } \\
\mathrm{N}+\mathrm{P}\end{array}$ & Nf-C & $\begin{array}{l}\text { Eg- } \\
\mathrm{P}\end{array}$ \\
\hline Nf-P & Eg-N & $\mathrm{Pp}-\mathrm{N}$ & $\begin{array}{l}\mathrm{Pa}- \\
\mathrm{N}+\mathrm{P}\end{array}$ & Nf-N & $\mathrm{Pa}-\mathrm{N}$ & $\begin{array}{l}\text { Pa- } \\
\text { C }\end{array}$ & $\begin{array}{l}\mathrm{Pp}- \\
\mathrm{N}+\mathrm{P}\end{array}$ & $\begin{array}{l}\text { Eg- } \\
\mathrm{N}\end{array}$ & $\mathrm{Pa}-\mathrm{C}$ & $\begin{array}{l}\text { Nf- } \\
\text { C }\end{array}$ & $\begin{array}{l}\mathrm{Eg}- \\
\mathrm{N}+\mathrm{P}\end{array}$ & $\begin{array}{l}\text { Pa- } \\
\text { C }\end{array}$ & $\begin{array}{l}\text { Pa- } \\
\text { N+P }\end{array}$ & $\begin{array}{l}\mathrm{Eg}- \\
\mathrm{N}+\mathrm{P}\end{array}$ & $\begin{array}{l}\text { Nf- } \\
\text { P }\end{array}$ \\
\hline
\end{tabular}

Figure 2. Physical layout of corn bioassays in a randomized block design. Each of the four regions corresponds to each of the four blocks (replicates). Within each of the blocks, each land use type soil ( $\mathrm{Nf}=$ native forest, $\mathrm{Pa}=\mathrm{pasture}, \mathrm{Eg}=$ Eucalyptus globulus plantation and $\mathrm{Pp}=$ Pinus patula plantation) was divided in four sub-units (four pots) and subjected to four treatments $(\mathrm{C}=$ control, with no fertilizer; $\mathrm{N}=$ nitrogen fertilizer; $\mathrm{P}=$ phosphorus fertilizer; $\mathrm{N}+\mathrm{P}=\mathrm{N}$ and $\mathrm{P}$ fertilizers), giving 16 randomly distributed combinations of soils (pots) and fertilizer applications from four land use types per block. 
ground to a fine powder in a cutting mill. Sub-samples of $0.2 \mathrm{~g}$ (for some smaller samples weight was recorded and the entire sample was used) were placed in digestion tubes with a solution composed of $\mathrm{Li}_{2} \mathrm{SO}_{4}$, selenium powder, $\mathrm{H}_{2} \mathrm{O}_{2} 30 \%$ and $\mathrm{H}_{2} \mathrm{SO}_{4} 18 \mathrm{M}$ [24]. Digestion tubes were placed on a preheated $\left(200^{\circ} \mathrm{C}\right)$ digestion block. The temperature was gradually increased to $340^{\circ} \mathrm{C}$ and samples were digested at this temperature for two hours. After digestion, each tube was brought to the same volume and analyzed for $\mathrm{K}, \mathrm{Ca}, \mathrm{Mg}$ and $\mathrm{Mn}$ by atomic absorption. Total N and P were analyzed by Flow Injection Analysis (TecatorFIAstar 5020 Analyzer).

Soil samples were air dried in a dark room at $14^{\circ} \mathrm{C}$. After air drying, they were passed through a $2 \mathrm{~mm}$ sieve for all extractions except for $\mathrm{PO}_{4}^{-}$, for which a sub-sample was ground to pass through a $150 \mu \mathrm{m}$ sieve. Mineral $\mathrm{N}$ $\left(\mathrm{NH}_{4}^{+}\right.$and $\mathrm{NO}_{3}^{-}$) was extracted with $\mathrm{KCl} 2 \mathrm{M}$ [25] and analyzed by Flow Injection Analysis (Tecator FIA star 5020 Analyzer). Exchangeable cations were extracted with $\mathrm{BaCl}_{2} 0.1 \mathrm{M}$ [26] and analyzed by atomic absorption. The effective cation exchange capacity (ECEC) was calculated by adding all cations. Exchangeable $\mathrm{P}\left(\mathrm{PO}_{4}^{-}\right)$ was extracted by the method of Bray II [27], using $\mathrm{NH}_{4} \mathrm{~F} 0.03 \mathrm{~N}+\mathrm{HCl} 0.1 \mathrm{~N}$, and analyzed by spectrophotometer. The percent soil organic matter content (\% SOM) was estimated by loss on ignition after combustion in the oven at $550^{\circ} \mathrm{C}$ for two hours [28]. Soil $\mathrm{pH}$ was determined from a 1:2 soil:water solution using a glass electrode.

\subsection{Statistical Analysis}

All plant tissue and soil variables were analyzed by a nested analysis of variance and a method for the determination of residual error [29]. Prior to ANOVA, data were tested for normality assumptions. If normality assumptions were not met, rank transformations were used. Following ANOVA, differences between means were tested using the Tukey means comparison test. Statistically significant differences are denoted by different letters between land use types (horizontally in tables) and between treatments (vertically in Table 3). All statistical analyses were done using SAS [30].

\section{Results}

\subsection{Treatment, Land Use and Region Effect}

For all of the soil chemical properties, the analysis of variance revealed a strong and significant effect of land use ( $p<0.0001$; Table 1) over the effect of region for which no statistical significance was revealed (Table 1). Land use ( $p=0.016$; Table 1 ) and region ( $p=0.033$; Table 1 ) effects were present for soil organic matter only, with stronger land use effect than region effect.

For the corn biomass and biomass nutrient content after conclusion of the bioassay experiment, the analysis of variance revealed a very strong treatment effect $(p<0.0001$; Table 1$)$ for all variables, but more importantly very highly significant land use effects for total biomass $(p=0.001$; Table 1$)$ and for K and Ca contents $(p \leq$ 0.005 ; Table 1$)$, and significant for Mg content ( $p=0.04$; Table 1). In contrast, land use effect was not significant for corn $\mathrm{N}$ and $\mathrm{P}$ contents (Table 1).

\subsection{Soil Characteristics}

From the four land use types, across the four regions, statistically significant differences were found for the soil variables that are linked to the $\mathrm{pH}$. Soil $\mathrm{pH}, \mathrm{Ca}$ and $\mathrm{Mg}$ concentrations were statistically lowest in pine soils, whereas $\mathrm{NH}_{4}^{+}-\mathrm{N}, \mathrm{Al}$ and Fe concentrations were highest ( $p \leq 0.05$; Table 2). In contrast, native forest soils had significantly higher $\mathrm{Ca}$ and $\mathrm{Mg}$ concentrations than pine soils ( $p \leq 0.05$; Table 2), but also higher coefficients of variation (Table 2). Only exchangeable $\mathrm{Ca}$ and $\mathrm{Mg}$ concentrations were higher in native soil compared to the soils of other land uses. Pasture and eucalyptus soils had the highest $\mathrm{pH}$, and lowest Fe concentrations in comparison to the other soils. Pasture soils also had the lowest $\mathrm{NH}_{4}^{+}-\mathrm{N}$ concentrations. Eucalyptus soils also had higher and comparable Mg concentration as in native forest soils with respect to the other soils $(p \leq 0.05)$. For the rest of soil variables there were no significant differences among land use types (Table 2).

\subsection{Corn Survival and Biomass}

Corn mortality occurred only in pine soils. Percent mortality of corn grown in soil from pine plantations and subjected to fertilizer treatment was: $\mathrm{N}=75 \%>\mathrm{C}=50 \%>\mathrm{NP}=38 \%>\mathrm{P}=25 \%$. One corn seedling survived in each pine soil pots given N-treatment in two blocks, and none survived in the other two blocks. In the P-treated pine soil pots, one seedling died in only one block out of four. This high mortality rate did not allow 
Table 1. Results from nested analysis of variance ( $\mathrm{F}$ and $p$-values) on soil and corn bioassay variables using soils collected in four land use types (native forest, pasture, eucalyptus plantation, pine plantation) in four separate regions of the southern Andes of Ecuador, and given four different fertilizer treatments (Control, N, $\mathrm{P}, \mathrm{N}+\mathrm{P}$ ) in a common garden bioassay experiment.

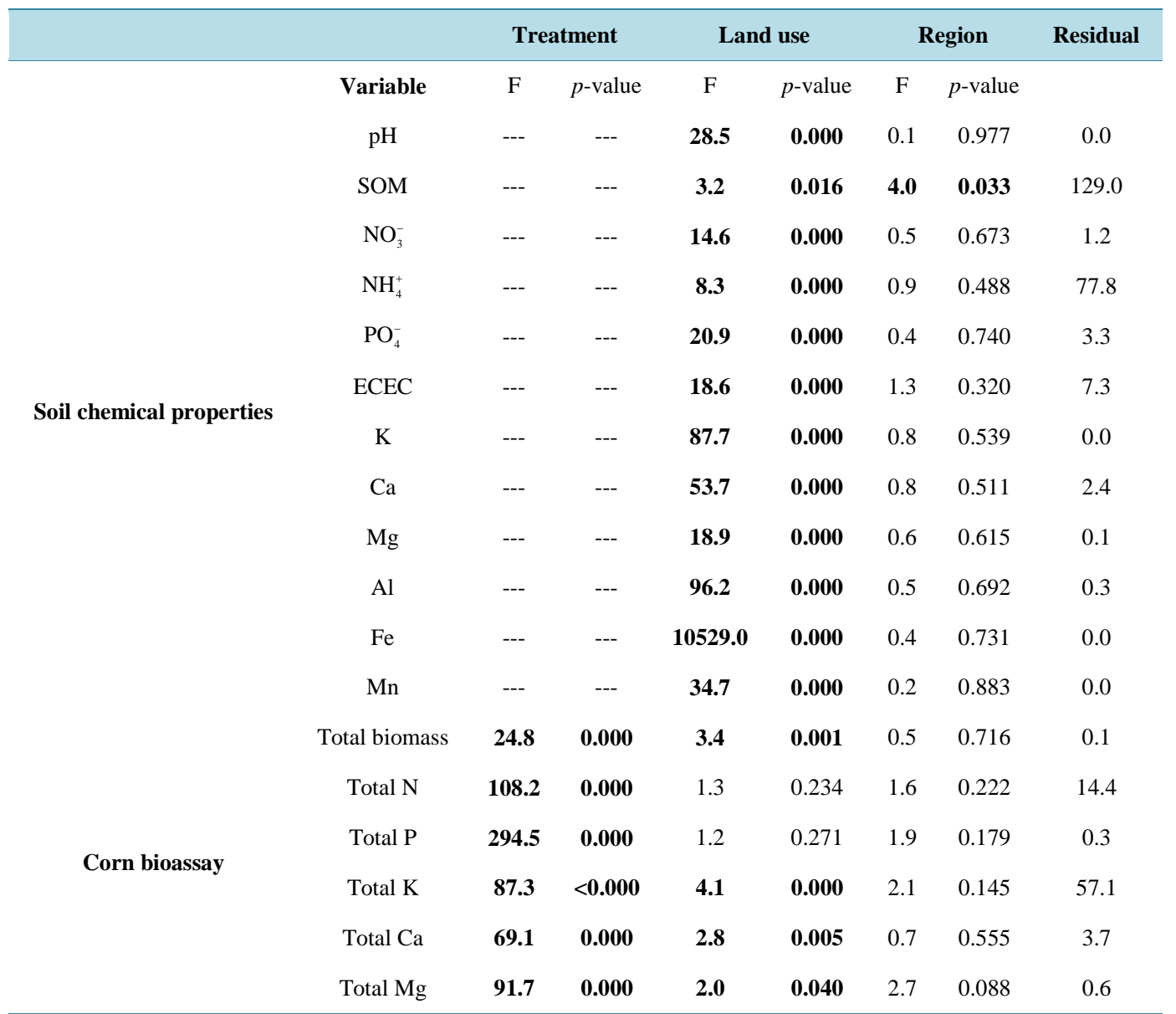

SOM = soil organic matter. ECEC = effective cation exchange capacity. Degrees of freedom for Treatment was 48; for Land use, 12; for Region, 3. Values in bold are statistically significant.

averages to be made of two plants to assess biomass and nutrient contents per plant as it did in all other experimental groups. Instead, individual values for corn biomass were summed when two plants survived per pot. When only one plant survived, this single biomass value was used. Therefore, data for biomasses and nutrient contents in Table 3 represent the actual production per pot.

Total corn biomass was statistically different among land use types only with the NP-treatment. Biomasses of corn were always significantly lower when grown in pine soils than if the corn were grown in native forest soils, with NP-treatment in both ( $p \leq 0.05$; Table 3 ). Between pasture and eucalyptus soils, corn biomasses were comparable and not significantly different from those in native forest or pine soils. Treatment effects showed a consistent increase of corn biomass with P- or NP-treatments compared to the N- or control treatments in all soils (statistically different at $p<0.01$; Table 3), with NP-treatment producing higher corn biomass than Ptreatment in native forest, pasture and eucalyptus soils, whereas $\mathrm{P}$ addition produced higher corn biomass than NP addition only in pine soils (Table 3).

\subsection{Corn Nutrient Content}

Corn total $\mathrm{N}$, total $\mathrm{Ca}$ and $\mathrm{Mg}$ were consistently and significantly higher in native forest soils than in pine soils with NP-treatment ( $p \leq 0.05$; Table 3). The same pattern, although with no significant differences, was found for total $\mathrm{P}$, and total $\mathrm{K}$. Total $\mathrm{N}$ was significantly higher for corn grown in eucalyptus and pasture soils, and 
Table 2. Comparison of initial soil properties before bioassay with corn. Soils are from four land use types in southern Ecuador, and from the first $20 \mathrm{~cm}$ of the soil profile $(n=4)$.

\begin{tabular}{|c|c|c|c|c|c|c|c|c|c|c|c|c|}
\hline \multirow[b]{2}{*}{ pH } & \multicolumn{3}{|c|}{ Native forest } & \multicolumn{3}{|c|}{ Pasture } & \multicolumn{3}{|c|}{ Eucalyptus globulus } & \multicolumn{3}{|c|}{ Pinus patula } \\
\hline & 5.2 & (9) & ab & 5.6 & (3) & $\mathbf{a}$ & 5.5 & $(6)$ & $\mathbf{a}$ & 4.9 & (3) & b \\
\hline$\%$ SOM & 39.9 & (68) & $\mathbf{a}$ & 30.1 & (47) & $\mathbf{a}$ & 29.7 & (66) & $\mathbf{a}$ & 36.6 & (18) & $\mathbf{a}$ \\
\hline $\begin{array}{c}\mathrm{NO}_{3}^{-} \\
\mathrm{mg} / \mathrm{kg}^{-1}\end{array}$ & 3.9 & (86) & $\mathbf{a}$ & 5.0 & (59) & $\mathbf{a}$ & 3.0 & (50) & $\mathbf{a}$ & 6.6 & $(47)$ & $\mathbf{a}$ \\
\hline $\begin{array}{c}\mathrm{NH}_{4}^{+} \\
\mathrm{mg} \cdot \mathrm{kg}^{-1}\end{array}$ & 42.3 & (74) & ab & 19.8 & (33) & b & 25.6 & (42) & ab & 46.1 & $(16)$ & $\mathbf{a}$ \\
\hline $\begin{array}{c}\mathrm{PO}_{4}^{-} \\
\mathrm{mg} / \mathrm{kg}^{-1}\end{array}$ & 8.9 & (58) & $\mathbf{a}$ & 6.7 & (128) & $\mathbf{a}$ & 3.3 & (2) & $\mathbf{a}$ & 6.3 & (51) & $\mathbf{a}$ \\
\hline $\begin{array}{c}\text { ECEC } \\
\mathrm{cmol} / \mathrm{kg}^{-1}\end{array}$ & 19.1 & (78) & $\mathbf{a}$ & 8.6 & (29) & $\mathbf{a}$ & 7.9 & (17) & $\mathbf{a}$ & 7.1 & $(16)$ & $\mathbf{a}$ \\
\hline $\begin{array}{c}\mathbf{K} \\
\mathrm{cmol} / \mathrm{kg}^{-1}\end{array}$ & 0.8 & (118) & $\mathbf{a}$ & 0.3 & (17) & $\mathbf{a}$ & 0.5 & (65) & $\mathbf{a}$ & 0.2 & (20) & $\mathbf{a}$ \\
\hline $\begin{array}{c}\text { Ca } \\
\mathrm{cmol} / \mathrm{kg}^{-1}\end{array}$ & 12.1 & (124) & $\mathbf{a}$ & 6.0 & (43) & ab & 4.2 & (47) & ab & 0.9 & (55) & b \\
\hline $\begin{array}{c}\text { Mg } \\
\mathrm{cmol} / \mathrm{kg}^{-1}\end{array}$ & 1.6 & (86) & $\mathbf{a}$ & 0.9 & (31) & ab & 1.0 & (41) & $\mathbf{a}$ & 0.2 & (26) & b \\
\hline $\begin{array}{c}\text { Al } \\
\mathrm{cmol} / \mathrm{kg}^{-1}\end{array}$ & 4.0 & (151) & ab & 1.0 & (53) & b & 1.9 & (61) & ab & 5.3 & (24) & $\mathbf{a}$ \\
\hline $\begin{array}{c}\mathbf{F e} \\
\mathrm{cmol} / \mathrm{kg}^{-1}\end{array}$ & 0.063 & (180) & $\mathbf{a}$ & 0.002 & (89) & b & 0.004 & (122) & b & 0.054 & (73) & $\mathbf{a}$ \\
\hline $\begin{array}{c}\text { Mn } \\
\mathrm{cmol} / \mathrm{kg}^{-1}\end{array}$ & 0.1 & (73) & a & 0.1 & (42) & a & 0.1 & (122) & $\mathbf{a}$ & 0.1 & (140) & $\mathbf{a}$ \\
\hline
\end{tabular}

SOM = Soil Organic Matter. ECEC = Effective Cation Exchange Capacity. Numbers in parentheses are coefficients of variation (in \%). Different letters represent significant differences at $p \leq 0.05$ between land use types.

lower in pine soils with $\mathrm{N}$-treatment ( $p \leq 0.05$; Table 3). Total $\mathrm{N}$ was not significantly different in native forest soils compared to the other land use type soils. For all other treatments and nutrients, statistically significant differences were absent among land use type soils.

Within land use types, significant treatment effects were absent for corn $\mathrm{N}$, P and $\mathrm{K}$ in pine soils and corn $\mathrm{K}$ in all land use type soils. In soils from native forest, pasture and eucalyptus land use types, corn $\mathrm{N}$ significantly increased only with the NP-treatment, whereas the N-treatment produced a corn $\mathrm{N}$ content very similar to that of the P- or control treatments ( $p \leq 0.01$; Table 3$)$. Corn $\mathrm{N}$ content remained low and similar with all treatments in pine soils (Table 3).

Corn P, K, Ca and Mg contents increased according to the incremental increase in corn biomass (Table 3) with P additions either with P- or NP-treatments in native forest, pasture and eucalyptus soils, whereas these nutrient contents decreased with either $\mathrm{N}$ - or control treatments $(p \leq 0.01$; Table 3$)$. In pine soils, the pattern is different, corn P, K, Ca and Mg contents considerably increased only with the P-treatment, and not with the other treatments (statistically significant differences present only for corn Ca and Mg at $p \leq 0.01$; Table 3).

Comparisons of nutrient concentrations in corn leaves analyzed in this experiment with critical nutrient concentration standards revealed nutrient deficiencies (Table 4). Critical nutrient concentration standards for corn presented in Table 4 are taken from data collected in Ontario, Canada [31], since no data could be found for Ecuador. Critical $\mathrm{N}$ concentration levels were found for corn grown in all land use type soils, except pine soils, in control and P-treatments. Critical P concentrations were found in corn grown on pasture and eucalyptus soils 
Table 3. Comparison of corn biomass and corn nutrient content after bioassay on soils from four land use types and under four fertilizer treatments in southern Ecuador ( $n=4$; for $P$. patula soils, $n$ specified left of each mean).

\begin{tabular}{|c|c|c|c|c|c|c|c|c|c|c|c|c|c|c|c|c|c|c|}
\hline \multirow[b]{2}{*}{ Total } & \multirow[b]{2}{*}{ C } & \multicolumn{4}{|c|}{ Native forest } & \multicolumn{3}{|c|}{ Pasture } & \multicolumn{5}{|c|}{ Eucalyptus globulus } & \multicolumn{5}{|c|}{ Pinus patula } \\
\hline & & 1.61 & (57) & $\mathbf{a}$ & $b$ & 1.57 & (17) & $\mathbf{a}$ & $b$ & 1.87 & (24) & $\mathbf{a}$ & $b$ & $n=2$ & 0.82 & (8) & $\mathbf{a}$ & $a$ \\
\hline Biomass & $\mathbf{N}$ & 1.77 & (73) & $\mathbf{a}$ & $b$ & 1.88 & (25) & $\mathbf{a}$ & $b$ & 1.69 & (30) & $\mathbf{a}$ & $b$ & $n=2$ & 0.41 & (56) & $\mathbf{a}$ & $a$ \\
\hline \multirow{3}{*}{$\mathrm{g} / \mathrm{pot}^{-1}$} & $\mathbf{P}$ & 3.37 & (73) & $\mathbf{a}$ & $a$ & 3.43 & (46) & $\mathbf{a}$ & $a$ & 3.17 & (43) & $\mathbf{a}$ & $a b$ & $n=3$ & 0.90 & (53) & $\mathbf{a}$ & $a$ \\
\hline & NP & 5.88 & $(65)$ & $\mathbf{a}$ & $a$ & 3.54 & (31) & ab & $a$ & 4.06 & (45) & ab & $a$ & $n=3$ & 0.51 & (62) & $\mathbf{b}$ & $a$ \\
\hline & C & 28.65 & $(60)$ & $\mathbf{a}$ & $b$ & 27.82 & (24) & $\mathbf{a}$ & $b$ & 29.73 & (36) & $\mathbf{a}$ & $b$ & $n=2$ & 21.44 & (17) & $\mathbf{a}$ & $a$ \\
\hline \multirow{4}{*}{$\begin{array}{l}\text { Total N } \\
\text { mg/pot }\end{array}$} & $\mathbf{N}$ & 52.70 & (51) & ab & $a b$ & 60.43 & (18) & a & $b$ & 57.51 & (14) & $\mathbf{a}$ & $b$ & $n=2$ & 15.66 & (53) & b & $a$ \\
\hline & $\mathbf{P}$ & 45.55 & (67) & $\mathbf{a}$ & $b$ & 43.61 & (59) & $\mathbf{a}$ & $b$ & 47.48 & (49) & $\mathbf{a}$ & $b$ & $n=3$ & 21.93 & (57) & $\mathbf{a}$ & $a$ \\
\hline & NP & 165.79 & (62) & a & $a$ & 111.67 & (24) & ab & $a$ & 129.75 & (53) & $\mathbf{a b}$ & $a$ & $n=3$ & 21.29 & (63) & b & $a$ \\
\hline & C & 1.91 & (35) & $\mathbf{a}$ & $b$ & 2.21 & (34) & $\mathbf{a}$ & $b$ & 2.07 & (16) & $\mathbf{a}$ & $b$ & $n=2$ & 1.78 & (16) & $\mathbf{a}$ & $a$ \\
\hline \multirow{4}{*}{$\begin{array}{c}\text { Total P } \\
\text { mg/pot }{ }^{-1}\end{array}$} & $\mathbf{N}$ & 2.39 & (47) & $\mathbf{a}$ & $a b$ & 2.58 & (44) & $\mathbf{a}$ & $b$ & 1.96 & (25) & $\mathbf{a}$ & $b$ & $n=2$ & 1.04 & (27) & $\mathbf{a}$ & $a$ \\
\hline & $\mathbf{P}$ & 15.23 & (64) & a & $a$ & 9.46 & (52) & a & $a$ & 11.24 & (79) & a & $a$ & $n=3$ & 4.43 & (47) & $\mathbf{a}$ & $a$ \\
\hline & NP & 17.01 & (70) & a & $a$ & 8.44 & (38) & a & $a$ & 10.57 & (71) & $\mathbf{a}$ & $a$ & $n=3$ & 2.27 & (54) & $\mathbf{a}$ & $a$ \\
\hline & C & 55.68 & (85) & a & $a$ & 60.85 & (39) & $\mathbf{a}$ & $a$ & 47.03 & (32) & $\mathbf{a}$ & $a$ & $n=2$ & 8.35 & (8) & a & $a$ \\
\hline \multirow{4}{*}{$\begin{array}{l}\text { Total K } \\
\mathrm{mg} / \operatorname{pot}^{-1}\end{array}$} & $\mathbf{N}$ & 59.94 & (95) & $\mathbf{a}$ & $a$ & 47.45 & (41) & $\mathbf{a}$ & $a$ & 46.51 & (59) & a & $a$ & $n=2$ & 3.47 & (69) & $\mathbf{a}$ & $a$ \\
\hline & $\mathbf{P}$ & 126.10 & (105) & $\mathbf{a}$ & $a$ & 94.20 & (64) & a & $a$ & 101.79 & (80) & $\mathbf{a}$ & $a$ & $n=3$ & 7.66 & (60) & $\mathbf{a}$ & $a$ \\
\hline & NP & 139.05 & (88) & $\mathbf{a}$ & $a$ & 96.88 & (60) & $\mathbf{a}$ & $a$ & 125.13 & (95) & $\mathbf{a}$ & $a$ & $n=3$ & 4.36 & (58) & $\mathbf{a}$ & $a$ \\
\hline & C & 10.51 & (74) & $\mathbf{a}$ & $b$ & 9.95 & (30) & $\mathbf{a}$ & $b$ & 9.22 & (56) & a & $b$ & $n=2$ & 1.33 & (18) & $\mathbf{a}$ & $a b$ \\
\hline \multirow{4}{*}{$\begin{array}{l}\text { Total Ca } \\
\text { mg/pot }{ }^{-1}\end{array}$} & $\mathbf{N}$ & 10.20 & (75) & $\mathbf{a}$ & $b$ & 10.85 & (14) & $\mathbf{a}$ & $b$ & 9.04 & (41) & a & $b$ & $n=2$ & 0.48 & (86) & $\mathbf{a}$ & $b$ \\
\hline & $\mathbf{P}$ & 27.51 & (71) & $\mathbf{a}$ & $a$ & 23.10 & (39) & $\mathbf{a}$ & $a$ & 20.85 & (38) & $\mathbf{a}$ & $a$ & $n=3$ & 4.50 & (75) & $\mathbf{a}$ & $a$ \\
\hline & NP & 38.09 & (66) & $\mathbf{a}$ & $a$ & 27.73 & (37) & $\mathbf{a b}$ & $a$ & 22.25 & (57) & ab & $a$ & $n=3$ & 1.23 & (68) & b & $a b$ \\
\hline & C & 5.41 & (80) & $\mathbf{a}$ & $a$ & 4.46 & (37) & a & $b$ & 5.47 & (43) & $\mathbf{a}$ & $a$ & $n=2$ & 1.20 & (17) & $\mathbf{a}$ & $a b$ \\
\hline \multirow{3}{*}{$\begin{array}{l}\text { Total Mg } \\
\text { mg/pot }\end{array}$} & $\mathbf{N}$ & 5.73 & (87) & a & $a$ & 5.47 & (21) & a & $b$ & 5.46 & (29) & a & $a$ & $n=2$ & 0.47 & (33) & $\mathbf{a}$ & $b$ \\
\hline & $\mathbf{P}$ & 10.66 & (84) & $\mathbf{a}$ & $a$ & 9.50 & (45) & a & $a b$ & 13.96 & (72) & $\mathbf{a}$ & $a$ & $n=3$ & 2.40 & (35) & $\mathbf{a}$ & $a$ \\
\hline & NP & 17.29 & (65) & $\mathbf{a}$ & $a$ & 13.33 & (31) & $\mathbf{a b}$ & $a$ & 13.12 & (61) & $\mathbf{a b}$ & $a$ & $n=3$ & 0.85 & (42) & b & $a b$ \\
\hline
\end{tabular}

Total $=$ Stem + Leaf + Root. Biomass data are the sum of two plants per pot, or one plant when mortality occurred. $\mathrm{C}=\mathrm{Control} . \mathrm{N}=\mathrm{Am}$ monium-nitrate fertilizer. $\mathrm{P}=$ Triple super phosphate fertilizer. $\mathrm{NP}=$ Combined N-P fertilizers. Numbers in parentheses are coefficients of variation (in \%). Different bold letters represent significant differences between land use types (horizontally) at $p \leq 0.05$. Different italic letters represent significant differences between treatments (vertically) at $p<0.01$.

in the control and N-treatments. Critical $\mathrm{K}$ and Ca concentrations were found in corn grown in pine soils only, irrespective of treatment (except for Ca in P-treatment). Corn foliar Mn concentration was above maximum normal level in pine soils for control and P-treatments.

\section{Discussion}

The high mortality rate and low response to fertilization in Pinus patula plantation soils indicate a low potential for agriculture on these soils. In contrast, there was a $100 \%$ survival rate of corn in all other soils and treatment groups. Generally, corn growth responded to P and NP-fertilizers in soils, excluding those from the pine plantations (Table 3). There was no response in the $\mathrm{N}$-treatment and growth was very similar to the one found in control soils. The combined effect of $\mathrm{N}$ and $\mathrm{PO}_{4}^{-}$significantly increased corn biomass. Thus, $\mathrm{N}$ and $\mathrm{PO}_{4}^{-}$are deficient in the studied soils, but $\mathrm{PO}_{4}^{-}$is the primary limiting factor. The same is true for nutrient contents (Table 3). The very low biomass of corn grown in control soils from all the land use types sampled in this study indicates a loss of agricultural potential through the reduction of soil fertility, which has lead to fertilization dependency to 
Table 4. Comparison of nutrient concentrations in leaves of bioassay corn with critical nutrient concentrations standards. Concentration below or near critical values are indicated in bold and underlined $(n=4)$.

\begin{tabular}{|c|c|c|c|c|c|c|c|}
\hline & & $\mathbf{N}$ & $\mathbf{P}$ & $\mathbf{K}$ & Ca & Mg & Mn \\
\hline & & $\%$ & $\%$ & $\%$ & $\%$ & $\%$ & $\mathrm{mg} / \mathrm{kg}^{-1}$ \\
\hline Land use types & Treatments & & & & & & \\
\hline $\mathbf{N f}$ & C & $\underline{2.2}$ & 0.22 & 2.9 & 0.72 & 0.5 & 83 \\
\hline $\mathbf{P a}$ & $\mathbf{C}$ & $\underline{2.2}$ & $\underline{0.17}$ & 3.8 & 0.85 & 0.4 & 74 \\
\hline Eg & $\mathbf{C}$ & $\underline{1.8}$ & $\underline{0.13}$ & 2.6 & 0.80 & 0.5 & 60 \\
\hline $\mathbf{P p}$ & C & 2.9 & 0.31 & $\underline{1.0}$ & $\underline{0.34}$ & 0.4 & 201 \\
\hline Nf & $\mathbf{N}$ & 3.8 & 0.32 & 2.6 & 0.61 & 0.5 & 83 \\
\hline $\mathbf{P a}$ & $\mathbf{N}$ & 3.4 & $\underline{0.14}$ & 2.5 & 0.78 & 0.4 & 79 \\
\hline Eg & $\mathbf{N}$ & 3.7 & $\underline{0.14}$ & 2.7 & 0.82 & 0.6 & 86 \\
\hline $\mathbf{P p}$ & $\mathbf{N}$ & 3.9 & 0.36 & $\underline{0.8}$ & $\underline{0.19}$ & 0.3 & 36 \\
\hline Nf & $\mathbf{P}$ & $\underline{2.0}$ & 0.76 & 2.8 & 0.97 & 0.4 & 118 \\
\hline $\mathbf{P a}$ & $\mathbf{P}$ & $\underline{1.6}$ & 0.29 & 2.9 & 0.92 & 0.4 & 78 \\
\hline Eg & $\mathbf{P}$ & $\underline{1.8}$ & 0.33 & 2.9 & 0.88 & 0.5 & 77 \\
\hline $\mathbf{P p}$ & $\mathbf{P}$ & 3.0 & 0.82 & $\underline{1.1}$ & 0.84 & 0.6 & 173 \\
\hline Nf & NP & 3.7 & 0.49 & 1.8 & 0.69 & 0.4 & 95 \\
\hline $\mathbf{P a}$ & NP & 3.4 & 0.24 & 2.4 & 0.88 & 0.5 & 81 \\
\hline Eg & NP & 3.4 & 0.27 & 2.4 & 0.71 & 0.4 & 61 \\
\hline Pp & NP & 4.5 & 0.72 & $\underline{0.8}$ & $\underline{0.39}$ & 0.4 & 138 \\
\hline Critical concentration $^{\mathrm{a}}$ & & 2.5 & 0.15 & 1.2 & $0.47^{\mathrm{b}}$ & 0.1 & 15 \\
\hline Max. normal concentration ${ }_{a}$ & & 3.5 & 0.50 & 2.5 & 1.50 & 0.6 & 150 \\
\hline
\end{tabular}

${ }^{\mathrm{a}}$ Critical concentration and maximum normal concentration for corn taken from OMAF [31]. ${ }^{\mathbf{b}}$ No critical concentration was given for Ca in OMAF [31]; we estimated a critical concentration for Ca, using P, $\mathrm{K}$ and $\mathrm{Mg}$ (average critical conc./max. normal concentration ratio for P, K, $\mathrm{Mg}=0.31$; Ca max. normal conc. $\times 0.31=0.47)$.

sustain crop production. For example, experiments with potatoes grown in Ecuadorian Andisols required P applications every cycle to obtain adequate yields [13].

The results presented here do not show that $\mathrm{N}$ and $\mathrm{PO}_{4}^{-}$supply was limited in pine soils. Corn foliar concentrations of $\mathrm{N}$ and $\mathrm{P}$ are above critical levels in corn grown in pine soils, although they were below critical levels in corn grown in control soils of almost all other land use types (Table 4). The trends seen for increased corn biomass were too small to be statistically significant (ex. effects of $\mathrm{P}$ additions are observed in corn $\mathrm{P}$ and cation contents). This suggests that growth was limited by other factors than $\mathrm{N}$ or $\mathrm{P}$, such as $\mathrm{Al}$ toxicity. Exchangeable $\mathrm{Al}$ was higher and $\mathrm{pH}$ lower in these soils, although differences were not significantly different with all other land use types. Other causes of the limited growth response to fertilizer $\mathrm{N}$ and $\mathrm{P}$ on pine plantations soil may be possible, for example allopathic effects or the effect of pathogens.

The contents of $\mathrm{P}$, Ca and $\mathrm{Mg}$, but not $\mathrm{K}$, statistically increased with $\mathrm{P}$ additions as opposed to $\mathrm{N}$ additions. One hypothesis is that $\mathrm{PO}_{4}^{-}$concentrations regulate $\mathrm{Ca}$ and $\mathrm{Mg}$ uptake by controlling the efflux pump in crops [32]. At low $\mathrm{PO}_{4}^{-}$concentrations, effluxes of $\mathrm{Mg}$ and $\mathrm{Ca}$ were reported from roots in wheat and tall fescue crops [33]. Foliar concentrations of $\mathrm{K}$ and $\mathrm{Ca}$ in corn grown on pine soils, irrespective of treatment (except for $\mathrm{Ca}$ in P-treatment) are below critical levels, whereas $\mathrm{Mn}$ is above maximum normal concentration in the control and P-treatments (Table 4). In pine soils, the effect of the Ca contained in the P-fertilizer treatment was to reduce soil acidity, and perhaps $\mathrm{Al}$ toxicity, and is likely to have improved corn growth, although we cannot separateit from the direct effect of $\mathrm{P}$. However, pine soil deficiencies, especially $\mathrm{K}$ and $\mathrm{Ca}$, were not eliminated to attain better growth. We can observe large increases of $\mathrm{K}$ content in corn, although not statistically significant, with P and NP-treatments in pasture and eucalyptus soils (Table 4). 
With regard to soil properties of the land use types reported here, the differences in corn biomass production and nutrient content are better compared between native forest, pasture and eucalyptus soils, exclusive of pine soils, which always produced lower biomass and nutrient contents, and can thus be considered to have lower productivity and fertility than all the other soils. Soils from native forests, pastures and eucalyptus plantations produced similar corn biomass and had similar nutrient contents, although some cation deficiencies are likely in pasture and eucalyptus soils. Corn accumulated statistically more $\mathrm{N}$ and $\mathrm{P}$ in the N-treatment grown in pasture soils than in pine soils, although its biomass was comparable. These results suggest additional deficiencies in the availability of other nutrients, such as $\mathrm{K}, \mathrm{Ca}$ and $\mathrm{Mg}$, because of a $\mathrm{N}$ and $\mathrm{PO}_{4}^{-}$enrichment in the absence of increased growth [34].

The results presented in this paper show that nutrient deficits impeded corn growth. Whether or not specific $\mathrm{P}$ and $\mathrm{N}$ deficiencies are present among the different land use types studied, soil deficiencies are indeed present at the land use level for $\mathrm{K}, \mathrm{Ca}$, and $\mathrm{Mg}$. In the case of the soils associated with pine plantations, reduced $\mathrm{K}, \mathrm{Ca}$ and Mg seems to be aggravated by a lower $\mathrm{pH}$. We can conclude that fertilizer applications in the studied soils should include $\mathrm{K}, \mathrm{Ca}$ and $\mathrm{Mg}$ in order to increase $\mathrm{pH}$ and to enhance SOM mineralization. Long term studies of soil phosphorus application [35], soil liming [36] and the application of organic amendments should be investigated for these soils.

The bioassay response to $\mathrm{N}$ and $\mathrm{P}$ fertilization indicated a low potential for agricultural production without nutrient amendments on all land use types. This potential was lowest for pine plantations and was not restored with $\mathrm{N}$ and $\mathrm{P}$ application. It is difficult to tease apart the role of inherent low soil nutrient availability from that of land uses. Nevertheless, it is likely that all land use types have been subjected to past impacts that have lowered soil fertility. Pine plantations represent an end point that may combine originally poor site and soil conditions with non-sustainable former land uses. Because agriculture, grazing pasture, afforestation of degraded lands and exotic forestry production continue to rise in the Andes of Ecuador, these results have far-reaching implications for sustainable land use management by large-scale agri-businesses, medium and small-sized farms, as well as government agencies interested in crop productivity. If better land use management is not practiced, soils will continue to decline in fertility, causing a continued decrease in agricultural productivity.

\section{Acknowledgements}

We gratefully acknowledge the Universidad del Azuay and ETAPA for laboratory facilities, equipment and logistics. We also wish to acknowledge the Biodôme de Montréal and Macdonald College (McGill University) for providing facilities for soil and plant tissue analyses. Thanks to Dr. Kathleen Farley, Dr. Wayne Hanson and an anonymous reviewer whose comments have helped to improve this paper. Thanks also to Jheimy Pacheco for drafting the map of the study area.

\section{References}

[1] García, F. (2006) El Sector Agrario del Ecuador: Incertidumbres (Riesgos) Ante la Globalización. Íconos, 24, 71-88.

[2] Bretón, V. (2008) From Agrarian Reform to Ethnodevelopment in the Highlands of Ecuador. Journal of Agrarian Change, 8, 583-617. http://dx.doi.org/10.1111/j.1471-0366.2008.00181.x

[3] Nieto-Cabrera, C., Francis, C., Caicedo, C., Gutiérrez, P.F. and Rivera, M. (1997) Response of Four Andean Crops to Rotation and Fertilization. Mountain Research and Development, 17, 273-282. http://dx.doi.org/10.2307/3673854

[4] Harden, C.P. and Hyman, G. (2007) Agriculture and Soil Erosion. In: Orme, T., Veblen, T. and Young, K., Eds., The Physical Geography of South America, Oxford University Press, Oxford, 289-304.

[5] Knoke, T., Bendix, J., Pohle, P., Hamer, U., Hildebrandt, P., Roos, K., Gerique, A., Sandoval, M.L., Breuer, L., Tischer, A., Silva, B., Calvas, B., Aguirre, N., Castro, L.M., Windhorst, D., Weber, M., Stimm, B., Günter, S., Palomeque, X., Mora, J., Mosandl, R. and Beck, E. (2014) Afforestation or Intense Pasturing Improve the Ecological and Economic Value of Abandoned Tropical Farmlands. Nature Communications, 5, 1-12. http://dx.doi.org/10.1038/ncomms6612

[6] Hofstede, R.G.M., Groenendijk, J.P., Coppus, R., Fehse, J.C. and Sevink, J. (2002) Impact of Pine Plantations on Soils and Vegetation in the Ecuadorian High Andes. Mountain Research and Development, 22, 159-167. http://dx.doi.org/10.1659/0276-4741(2002)022[0159:IOPPOS]2.0.CO;2

[7] Podwojewski, P., Poulenard, J., Zambrana, T. and Hofstede, R. (2002) Overgrazing Effects on Vegetation Cover and Properties of Volcanic Ash Soil in the Páramo of Llangahua and La Esperanza (Tungurahua, Ecuador). Soil Use and Management, 18, 45-55. http://dx.doi.org/10.1079/SUM2002100 
[8] Farley, K.A. and Kelly, E.F. (2004) Effects of Afforestation of a Páramo Grassland on Soil Nutrient Status. Forest Ecology and Management, 195, 281-290. http://dx.doi.org/10.1016/j.foreco.2003.12.015

[9] Buytaert, W., Deckers, J. and Wyseure, G. (2006) Description and Classification of Nonallophanic Andosols in South Ecuadorian Alpine Grasslands (Páramo). Geomorphology, 73, 207-221. http://dx.doi.org/10.1016/j.geomorph.2005.06.012

[10] Chacón, G., Gagnon, D. and Paré, D. (2009) Comparison of Soil Properties of Native Forests and Pinus patula Plantations, and Pastures in the Andean highlands of southern Ecuador: Land-Use History or Recent Vegetation Effects? Soil Use and Management, 25, 427-433. http://dx.doi.org/10.1111/j.1475-2743.2009.00233.x

[11] Harden, C.P. (2006) Human Impacts on Headwater Fluvial Systems in the Northern and Central Andes. Geomorphology, 79, 249-263. http://dx.doi.org/10.1016/j.geomorph.2006.06.021

[12] Bossio, D.A. and Cassman, K.G. (1991) Traditional Rainfed Barley Production in the Andean Highlands of Ecuador: Soil Nutrient Limitations and Other Constraints. Mountain Research and Development, 11, 115-126. http://dx.doi.org/10.2307/3673571

[13] Espinosa, J. (1992) Phosphorus Diagnosis and Recommendations in Volcanic Ash Soils. PDSS Proceedings, Trop Soils Bulletin, 92, 109-115.

[14] Chacón-Vintimilla, G., Gagnon, D., Paré, D. and Proulx, D. (2003) Impacto de la Deforestación, Pastizales, Plantaciones de Eucalipto y Pino en Suelos de Bosque Montano Alto, en la Sierra Sur del Ecuador. Revista de Investigaciones de la Universidad del Azuay, 11, 19-34.

[15] Shoji, S., Nanzyo, M. and Dahlgren, R. (1993) Productivity and Utilization of Volcanic Ash Soils. In: Shoji, S., Nanzyo, M. and Dahlgreen, R., Eds., Volcanic Ash Soils: Genesis, Properties and Utilization, Elsevier, Amsterdam, 209251. http://dx.doi.org/10.1016/S0166-2481(08)70269-1

[16] Oades, J.M., Guillman, G.P. and Uehara, G. (1989) Interactions of Soil Organic Matter and Variable-Charge Clays. In: Coleman, D.C., Oades, J.M. and Uehara, G., Eds., Dynamics of Soil Organic Matter in Tropical Ecosystems, NifTAL Project, Honolulu, 69-95.

[17] Uehara, G. and Gillman, G. (1981) The Mineralogy, Chemistry, and Physics of Tropical Soils with Variable-Charge Clays. West-View Press, Boulder.

[18] Buytaert, W., Deckers, J. and Wyseure, G. (2007) Regional Variability of Volcanic Ash Soils in South Ecuador: The Relation with Parent Material, Climate and Land-Use. Catena, 70, 143-154. http://dx.doi.org/10.1016/j.catena.2006.08.003

[19] Chacón-Vintimilla, G. (2002) Impact of Exotic Tree Plantations and Pastures on Soil Productivity in the Andean Highlands of Southern Ecuador. PhD Dissertation, Université du Québec à Montréal, Montreal.

[20] Farley, K.A., Bremer, L.L., Harden, C.P. and Hartsig, J. (2013) Changes in Carbon Storage under Alternative Land Uses in Biodiverse Andean Grasslands: Implications for Payment for Ecosystem Services. Conservation Letters, 6, 2127.

[21] Harden, C.P., Hartsig, J., Farley, K.A., Lee, J. and Bremer, L.L. (2013) Effects of Land-Use Change on Water in Andean Páramo Grassland Soils. Annals of the Association of American Geographers, 103, 375-384. http://dx.doi.org/10.1080/00045608.2013.754655

[22] Celleri, R., Willems, P., Buytaert, W. and Feyen, J. (2007) Space-Time Rainfall Variability in the Paute Basin, Ecuadorian Andes. Hydrological Processes, 21, 3316-3327. http://dx.doi.org/10.1002/hyp.6575

[23] Hall, M.N. and Calle, J. (1982) Geochronological Control for the Main Tectonic-Magmatic Events of Ecuador. EarthScience Reviews, 18, 215-239. http://dx.doi.org/10.1016/0012-8252(82)90038-1

[24] Allen, S. (1989) Analysis of Vegetation and Other Organic Materials. In: Allen, D., Ed., Chemical Analysis of Ecological Materials, Blackwell, Oxford, 46-61.

[25] Maynard, D.G. and Kalra, Y.P. (1993) Nitrate and Exchangeable Ammonium Nitrogen. In: Carter, M.R., Ed., Soil Sampling and Methods of Analysis, Lewis Publishers, Boca Raton, 25-38.

[26] Hendershot, W.H., Lalande, H. and Duquette, M. (1993) Soil Reaction and Exchangeable Acidity. In: Carter, M.R., Ed., Soil Sampling and Methods of Analysis, Lewis Publishers, Boca Raton, 141-145.

[27] McKeague, J.A. (1978) Manuel de méthodes d'échantillonage et d’analyse des sols. Comité Canadien de Pédologie, Ottawa.

[28] Grimshaw, H.M. (1989) Analysis of Soil. In: Allen, S.E. and Stewart, A., Eds., Chemical Analysis of Ecological Materials, Blackwell, Oxford, 7-45.

[29] Lenth, R.V. (1989) Quick and Easy Analysis of Unreplicated Factorials. Technometrics, 31, 469-473. http://dx.doi.org/10.1080/00401706.1989.10488595

[30] SAS Institute Inc. (2008) SAS/STAT® 9.2 User’s Guide. SAS Institute Inc., Cary. 
[31] OMAF Ontario Ministry of Agriculture and Food (1988) 1989-1990 Field Crop Recommendations. Queens Printer for Ontario, Publication 296.

[32] Blevins, D.G. (1994) Uptake, Translocation, and Function of Essential Mineral Elements in Crop Plants. In: Boote, K.J., Bennett, J.M., Sinclair, T.R. and Paulsen, G.M., Eds., Physiology and Determination of Crop Yield, American Society of Agronomy, Crop Science Society of America, Soil Science Society of America, Madison, 259-275.

[33] Reinbott, T.M. and Blevins, D.G. (1991) Phosphate Interaction with Uptake and Leaf Concentration of Magnesium, Calcium, and Potassium in Winter Wheat Seedlings. Agronomy Journal, 83, 1043-1046. http://dx.doi.org/10.2134/agronj1991.00021962008300060021x

[34] Denslow, J.S., Vitousek, P.M. and Schultz, J.C. (1987) Bioassays of Nutrient Limitation in a Tropical Rain Forest Soil. Oecologia, 74, 370-376. http://dx.doi.org/10.1007/BF00378932

[35] Antoniadis, V., Hatzis, F., Bachtsevanidis, D. and Koutroubas, S.D. (2015) Phosphorus Availability in Low-P and Acidic Soils as Affected by Liming and P Addition. Communications in Soil Science and Plant Analysis, 46, 12881298. http://dx.doi.org/10.1080/00103624.2015.1033539

[36] Jaskulsca, I., Jaskulski, D. and Kobierski, M. (2014) Effect of Liming on the Change of Some Agrochemical Soil Properties in a Long-Term Fertilization Experiment. Plant, Soil and Environment, 60, 146-150. 